\title{
Pojetí mentoringu
}

\section{u začínajících učitelů \\ v České republice a Velké Británii}

\section{Andrea Pazderská}

\begin{abstract}
Abstrakt
Příspěvek objasní základní kontury fungování současného mentoringu začínajících učitelů v České republice a Velké Británii s cílem nastínit možnosti aplikace vybraných aspektů zahraniční praxe v českém prostředí. Teoretické východisko příspěvku se opírá o pojetí mentoringu jakožto procesu, který představuje cílenou a odbornou podporu profesního rozvoje učitelů v různých fázích jejich profesní pedagogické dráhy. Mentor má za úkol pomocí mentorských rozhovorů a přiležitostných hospitací učitele vést, ukazovat jim další možné cesty jejich profesního rozvoje a umožnit jim vlastní sebereflexi jejich pedagogické praxe. Metodologicky se jedná o kvalitativně-kvantitativní empirický výzkum. Data jsou po celou dobu výzkumu získávána analýzou české a především zahraniční odborné literatury a v praxi dále ověřována exploračními metodami.
\end{abstract}

Klíčová slova: mentoring, mentor, tutor, kvalita učitele, příprava budoucích učitelů, pedagogická praxe, začínající učitel 


\title{
The conception of the mentoring by the novice teachers in the Czech Republic and Great Britain
}

\begin{abstract}
The paper introduces the basic contours of the functioning of the current system of the mentoring by the novice teachers in the Czech Republic and the United Kingdom with the goal to outline the possible applications of the selected aspects from the international practice in the Czech Republic. The theoretical foundation of this contribution is based on the concept of the mentoring as the process, which represents the targeted support of the teacher professional development at different stages of their professional teaching career. The mentor has the task to lead the teachers, to show them further possible ways of their professional development and to enable them their own self-reflection of their teaching practice with the help of the mentoring dialogues and occasional classroom inspections. Methodologically it is the qualitative and quantitative empirical research. The data is, for the whole duration of the research, obtained by analysing Czech and mainly foreign literature and verified in practice by further exploratory methods.
\end{abstract}

Key words: mentoring, mentor, tutor, teacher quality, initial teacher training, pedagogical practice, novice teacher

\section{Úvod}

Dějiny pedagogiky i náš aktuální pohled na současnou situaci školního vzdělávání nejen v České republice potvrzují, že kvalita pedagogických pracovníků je činitelem, který se zcela klíčovým způsobem podílí na formování kvalitativní úrovně školního vzdělávání jakožto celku (Tomková, Spilková 2012, s. 6). Praktickým dokladem této vstupní teoretické premisy je pak skutečnost, že výsledky některých nedávných bádání také v exaktní rovině prokázaly, že právě kvalita učitelů má na vzdělávací výsledky žáků častokrát větší vliv, než např. kvalita kurikula nebo materiální vybavenost školských zařízení (Hattie 2003, Barber; Mourshed 2007 in Tomková, Spilková 2012, s. 6). Mentoring, kterým se budu zabývat níže, je pak bezesporu jedním z nejvýznamnějších současných nástrojů ke zvyšování kvality pedagogů, jemuž je však často neprávem přisuzován jen relativně malý význam. S ohledem na soudobé možnosti zvyšování kvalitativní úrovně učitelské profese si však dle mého soudu problematika mentoringu rozhodně zaslouží bližší pozornost, a to nejen ze strany samotných aktérů tohoto procesu (tj. vzdělavatelů učitelů, začínajících učitelů a učitelů zkušených), ale ve svých důsledcích i ze strany státu, zejména s ohledem na potenciální formy státní podpory. 


\section{Pojem mentoringu a jeho dosavadní reflexe}

Ačkoliv je téma mentoringu rozpracováno především v anglosaských zemích, odkud také samotný název pochází a kde je zároveň hojně aplikován v praxi, nejedná se o pojem zcela nový. S pojmem mentor se setkáváme již u jedné z postav starověkých Homérových eposů, konkrétně u muže, který se ujal výchovy malého Telemacha v momentě, kdy se jeho otec Odysseus odebral do Trójské války. Těžiště úkolu tohoto Mentora Ize spatřovat prakticky ve všech aspektech, jež obnáší ono „suplování“ otcovské role, tj. vytvářet malému chlapci osobnostní príklad, poradit mu, motivovat jej a v prípadě potřeby mu být vždy nápomocen (Carruthers 1993, s. 9 in Píšová 2011).V pedagogice zůstaly mnohé z těchto významů zachovány, nebot' v teoretickém vymezení má být mentor pro (nejen) budoucího učitele zkušenějším, důvěryhodným rádcem a průvodcem (Píšová 2005 in Píšová 2011, s. 40). Několik jasných příkladů mentorských vztahů však nalezneme i v pozdější historii, kde nám za příklad může posloužit duo Aristotela a Alexandra Makedonského, biskupa Ambrože a sv. Augustina či Františka Palackého a F. L. Riegera.

$V$ průběhu osmdesátých let minulého století začaly různé formy mentoringu postupně pronikat i do sociálního sektoru a školství, a to zejména do př́pravného vzdělávání učitelů (Parsloe, Wary 2000 in Píšová 2011). V České republice se doposud nesetkáváme se žádným formalizovaným systémem mentoringu. $V$ jisté formě zde však existoval model uvádění začínajících učitelů do praxe (tzv. uvádějící učitel), který byl zaveden ve druhé polovině sedmdesátých let minulého století, ale byl bohužel v roce 1989 (formálně) zrušen, přičemž nebyl nahrazen žádným obdobným funkčním programem (Píšová 2011, s. 6). V současné době se s tematizací mentoringu setkáváme v mnoha zemích, na poli evropském například v nám geograficky i kulturně blízkém Německu, kde je mentoring plnou a funkční součástí zvláště u přípravy začínajících učitelů ( $v$ rámci plnění jejich jedno až dvouleté praxe v rámci Referandiarat) (Frieß 2010, s. 6-7). V Holandsku je problematika mentoringu již plně formálně začleněna do učitelské praxe, kdy mentor je zkušený učitel se sníženým úvazkem, jenž pomáhá začínajícím, ale i zkušeným učitelům na jejich žádost s dalším profesním rozvojem (Kargerová 2008, s. 8). Ve Velké Británii je pojem mentor taktéž pevně formálně zakotven v průběhu praxe začínajících učitelů a jejich prvního roku praxe (tzv. Induction Period).

V českém prostředí je přitom téma mentoringu doposud zpracováno především teoreticky (srov. Píšová, Duschinská 2011; Petrášová, Štěpánek, Prausová 2014), nicméně v posledních letech dala aktuální potřebnost tématu za vznik také poměrně pestré mozaice různých projektů, občanských sdružení, seminářu a kurzů, jež mají společný cíl, kterým je právě zavádění mentoringu do praxe. Ačkoliv nemá Česká republika doposud žádný formalizovaný systém podpory profesního rozvoje učitelů, který by byl plošně aplikován na českých základních a středních školách, je tato široká nabídka různých, mnohdy velmi dobře rozpracovaných, systémů prípravy mentorů a mentoringu samotného velmi kvalitní a lehce aplikovatelná v praxi. Bohužel jim dosud chybí jednotná 
struktura, sdílení informací, užitečných zkušeností a jednotná formální zastřešenost (srov. Píšová 2011, s. 30-34).

V návaznosti na tento fakt je cílem předkládaného příspěvku především seznámit širší publikum s pojmem mentoringu, nastínit aktuální situaci v českém prostředí a představit fungování mentoringu ve Velké Británii, kde je již plně formálně začleněn do uvádění začínajících učitelů.

\subsection{Teoretické vymezení mentoringu}

V pedagogice se pod pojmem mentoring chápe proces, který představuje cílenou a odbornou podporu profesního rozvoje učitelů v různých fázích jejich profesní pedagogické dráhy (Píšová 2011, s. 41). Mentor zde má za úkol pomocí mentorských rozhovorů a př́ležitostných hospitací učitele vést, ukazovat jim další možné cesty jejich profesního rozvoje a umožnit jim vlastní sebereflexi pedagogické praxe (Nešpor, Lukáš 2005, s. 6-7). Mentor je přitom v celém průběhu mentoringu zodpovědný za proces, za finální výsledek nese zodpovědnost pouze mentorovaný učitel (Vychodil 2011, s. 26-27). Mentoringem se pak v užším slova smyslu rozumí vztah mezi mentorem (zkušeným učitelem) a tzv. menteem. Obdobný pohled na problematiku mentoringu nabízí i v českém prostředí známý David Clutterbuck (2004), který definuje mentoring jako proces, ,", němž je jedna osoba (mentor) zodpovědná za dohled na kariéru a rozvoj jiné osoby (mentee), a to mimo přímou linii subordinace (podřízený/nadřízený)." (srov. Clutterbuck 2004 in Píšová 2011 s. 41).

Guest (2000) charakterizuje mentora jako moudrého a důvěryhodného rádce s odpovídající zkušeností, který měl možnost být v pozici mentorovaného a který je menteemu diskretním průvodcem a podporuje jej v jeho profesním rozvoji (Guest 2000 in Duschinská 2010, s. 8).

Termínem mentee je poté označován žák, začínající nebo již zkušenější učitel, který stojí v pozici mentrovaného. Mentee si často určuje oblast, kterou si přeje rozvíjet a na kterou se posléze s mentorem zaměřují ve snaze ji zdokonalit. Je to právě mentee, jenž si stanovuje cíle zlepšení a jenž (v případě již zkušených učitelů) vyhledává pomoc mentora právě za účelem zlepšení svých pedagogických dovedností.

Mentorský vztah je vztahem, který je dlouhodobý, podporující, rozvíjející a nehodnotící Je tedy založen především na sebereflexi. Dále mưžeme mentoring rozdělit na mentoring externí a interní. Externím mentoringem se rozumí mentoring poskytovaný učiteli vně školy (tj. mentor není součástí školy). Jeho výhodou je profesní nadhled, neutralita mentora a často zkušenosti s různými typy škol. Interním mentoringem se naopak rozumí mentoring probíhající v prostředí školy, kde je mentor součástí učitelského kolektivu a jeho výhodou tudíž je znalost prostředí, zdrojů a osobnější vztahy (Šneberger 2014, s. 19). 


\section{Stav mentoringu v České republice}

Jak již bylo naznačeno výše, přestože nemá Česká republika žádný formalizovaný systém mentoringu, vzniklo a vzniká na poli českého školství několik desítek projektů a programů, které se mentoringem zabývají, at už jako svým primárním nebo sekundárním cílem. $V$ této kapitole proto uvádím průřez těmito vybranými programy jakožto alespoň stručné nastínění barevné mozaiky mentoringových programů u nás.

\subsection{Program Začít spolu (1994)}

Vzdělávací program Začít spolu je zaštítěn mezinárodní asociací ISSA (International Step by Step Association) a od roku 1994 se souhlasem MŠMT ČR realizován na mateřských a od roku 1996 na základních školách. V současné době je $v$ tomto projektu zapojeno na jedno sto mateřských a sedmdesát základních škol v České republice. Jádrem vzdělávacího programu Začít spolu je pedagogický prístup orientovaný na dítě. Tento program je zároveň velkou podporou i pro další vzdělávání učitelů. Podpora mentoringu zde vznikla v podstatě jako "vedlejší produkt" při pomoci učitelům, kteří měli zájem o certifikaci Ocenění kvality pedagogické práce. Všem zúčastněným zemím byl představen interní dokument pod názvem Mentoring Teaching Curriculum, který byl následně upraven pro české prostředí s názvem Př́ručka pro mentory - Zvyšování pedagogických kompetencí pomocí ISSA ${ }^{1}$ pedagogických standardů (2006). V letech 2006- 2007 byly uspořádány první kurzy mentorských dovedností v Praze a Brně, které byly určeny zejména pro zástupce ředitelů škol provádějící hospitace, lektory dalšího vzdělávání, uvádějící učitele, vysokoškolské pedagogiky, certifikátory ISSA a další zájemce. Na tyto kurzy dále navazoval další projekt ${ }^{2}$, který cílil na učitele II. stupně a jehož součástí bylo taktéž vzdělávání mentorů v rámci třídenního rozšiřujícího kurzu mentorských dovedností a dále podpory vybraných učitelů prostřednictvím externího mentoringu. Tento program garantuje americká nezisková organizace Children's Resources International Washington D. C. a je finančně podporován nadací Open Society Fund. (Píšová 2011, s. 147-157).

\subsection{Akreditovaný program Rozvoj mentorských dovedností (2010)}

Kurz s názvem Rozvoj mentorských dovedností byl vyvinut, pilotně ověřen a nabízen Katedrou primární pedagogiky Univerzity Karlovy především fakultním učitelům-mentorům, kteří již mají zkušenosti s vedením studentů učitelství. $V$ praxi má tento kurz podobu široké palety pracovních dílen, které měly výrazně vývojový charakter a kde

ISSA - International Step by Step Association.

2 Projekt Diferenciace - Zavádění nových metod a forem práce na II. Stupni ZŠ s využitím mentorské podpory. 
byl tudíž vyvíjen koncepční, obsahový a organizační model podpory práce učitele a studenta učitelství s využitím mentoringu. Zároveň zde byly mapovány vzdělávací potřeby fakultních učitelů v oblasti vedení praxí studentů. Cílem kurzu bylo vést účastníky k porozumění mentoringu a jeho hlavním tématům. Zvláštní důraz byl přitom kladen na rozvoj mentorských dovedností a možnost "trénování" těchto dovedností formou rozhovorů, videopozorování a příklady z praxe již zkušených mentorů. Účastníci, fakultní i vysokoškolští učitelé, se poté stali spoluautory konečné, akreditované podoby kurzu Rozvoj mentorských dovedností. Tento kurz byl realizován za podpory grantu Open Society Institute $v$ rámci projektu Mentorská podpora studentů pedagogiky a běžel ve spolupráci se Step by Step ČR. (Spilková, Tomková a kol. 2015, s. 123-126).

\subsection{Projekt Mentoringem ke kvalitě (2013-2014)}

Další, poměrně zdařilý projekt v oblasti mentoringu u nás nabídl program Mentoringem ke kvalitě. Tento projekt se zaměřil především na profesní rozvoj pedagogických pracovníků a jedním z jeho dílčích cílů bylo zavedení interního mentoringu do škol. V rámci projektu vznikl rozsáhlý dokument Metodika práce s kompetenčním modelem (Šneberger 2014), jehož součástí je představení mentoringu učitelům základních a středních škol a také návrh využití kompetenčního rámce ve vztahu k mentoringu v české praxi.

\subsection{Projekt pomáháme školám k úspěchu (2010-2015)}

Projekt pomáháme školám k úspěchu je dlouhodobý vzdělávací projekt zaměřen na veřejné základní školy v České republice. Cílem projektu je zkvalitnit výuku na školách skrze podporu zapojené školy poskytováním její vzdělávací, materiální a personální podpory. K roku 2015 bylo do projektu zapojeno na 400 pedagogů a přes 6000 žáků. Jednou z forem podpory je právě podpora pedagogického vedení a dalšího vzdělávání pedagogických pracovníků formou mentoringu. Učitelé v zapojených školách mají možnost vyzkoušet si práci mentora, sdílet zkušenosti se svými kolegy a získat vzdělání v problematice mentorství. $V$ rámci projektu vznikají modelové školy ( $v$ současnosti existuje 7 modelových škol), které mají být ukázkou nejen toho, jak může vypadat škola zaměřená na úspěch každého žáka, ale také škola, kde je mentoring díky projektu již její přirozenou součástí. Mezi modelové školy patří např. ZŠ Kunratice v Praze, ZŠ Zdice ve Středočeském kraji, ZŠ a MŠ Horka nad Moravou v kraji Olomouckém a ZŠ Liberec. Projekt iniciovala a finančně podporovala Nadace The Kellner Family Foundation spolu s záštitou Ministerstva školství, mládeže a tělovýchovy ČR (http://www.kellnerfoundation.cz/pomahame-skolam-k-uspechu). 


\section{5 Česká asociace mentoringu ve vzdělávání}

Na poli českého vzdělávání vznikla v roce 2013 nevládní a nepolitická organizace Česká asociace mentoringu ve vzdělávání (www.camv.cz). K cílům asociace náleží usilovat o rozvoj mentoringu jak v rovině teoretické, tak i praktické. Tato česká asociace nabízí informace, vzdělávací kurzy a podporu mentoringu pro mentory, učitele, školy a další vzdělávací organizace. Základní tým České asociace mentoringu ve vzdělávání tvoří šest členů, mezi nimi i významná česká pedagožka a psycholožka, doc. PhDr. Bohumíra Lazarová, Ph.D., která je vicepresidentka asociace. Kromě toho pořádá Česká asociace téměř pravidelné tématické supervize po celé České republice, je zapojena do několika projektů, po placené registraci nabízí materiály ke studiu v oblasti problematiky mentoringu a nakonec uvádí také seznam certifikovaných mentorů rozrazených dle oblastí působnosti (podle krajů), které mají všichni učitelé možnost kontaktovat a kdykoliv požádat o radu a pomoc.

\subsection{Klinický rok - specifický model celoroční pedagogické praxe (2001/2002 a 2009/2010)}

Klinický rok byl zajímavým modelem pedagogické praxe, který v akademických letech 2001/2002-2009/2010 realizovala Univerzita Pardubice v rámci pětiletého magisterského studia oboru Učitelství pro základní školy - jednooborového studia Učitelství anglického jazyka. Cílem Klinického roku bylo umožnit studentům dlouhodobou reflektovanou pedagogickou praxi. Projektu se zúčastnily tři studentky ve 4. ročníku, které působily po jeden akademický rok ${ }^{3}$ na vybrané základní škole, kde pracovaly po boku zkušeného učitele - mentora. Tento mentor, který byl zkušeným učitelem z tamější školy, fungoval v roli uvádějícího učitele a jakéhosi průvodce studenta. Mimoto byl každé ze studentek přidělen tutor, tj. didaktik z univerzity, se kterým studentky jednak konzultovaly průběh pedagogické praxe, a který jim současně zadával úkoly a doporučoval příslušnou odbornou literaturu. Tento model pedagogické praxe byl bohužel ukončen v akademickém roce 2009/2010 v návaznosti na zavedení strukturovaného magisterského studia. I přes toto jeho krátké trvání byl ale velmi přínosný nejen pro studentky, které měly možnost strávit místo několika desítek hodin praxe ve škole celý jeden rok, ale i pro učitele - mentory, kteří měli možnost úzce spolupracovat s didaktiky Univerzity Pardubice a tím prohloubit nejen vzájemnou spolupráci, ale také obohatit svůj vlastní profesní rozvoj (Spilková, Tomková a kol. 2015, s. 145-147). Tento model Klinického roku se ostatně velmi podobal (zde můžeme spatřovat první analogii) anglickému modelu prvního roku praxe tzv. Induction Year který bude popsán v následující kapitole.

3 Studentky strávily na škole jeden celý školní rok (od přípravného týdne v srpnu do konce června) a vyučovaly 4 dny v týdnu. Poslední zbývající den byl vyčleněn pro plnění úkolů zadaných fakultou - jejich fakultním didaktikem, tutorem. 


\section{Stav mentoringu ve Velké Británii ${ }^{4}$}

Př́prava učitelů ve Velké Británii má oproti České republice konsekutivní neboli následovný charakter, což znamená, že budoucí učitelé nejprve absolvují povinnou teoretickou př́pravu na jedné z pedagogických vysokých škol a až poté plní prípravu praktickou v rámci tzv. Induction period, a to v délce jednoho akademického roku, při kterém vyučují na zvolené škole (Dixie, Bell s. 13-30). Právě během této jednoroční praxe na školách, jež bývá klíčovým okamžikem v přípravě budoucího učitele, absolventi získávají „k ruce“ mentora, který je provází jejich prvním rokem praxe.

\subsection{Mentoring jako podpora v rámci pedagogické praxe studentů}

Jak uvádějí autoři Burley a Pomphrey ve své publikaci Mentoring a Coaching ve školách, s mentoringem se ve Velké Británii setkáváme převážně v těchto čtyřech oblastech: v počátečním vzdělávání učitelů na začátku jejich profesního vývoje, v rámci jejich celoživotního profesního rozvoje, u vedení (leadership) a poté v širším vzdělávacím kontextu (Burley, Pomphrey 2011, s. 36-41).V mém příspěvku se ovšem zaměrím pouze na počáteční vzdělávání učitelů.

Praxe mentoringu jakožto podpory studentů učitelství má ve Velké Británii tradici již přes 20 let, tedy od doby, kdy ministerstvo vzdělávání upozornilo na nedostačující spolupráci základních a středních škol se školami vysokými připravujícími budoucí učitele. Toto tvrzení spustilo obrovskou lavinu akademické pozornosti - srov. Hagger (1993), Watkins a Whalley (1993), Furlong a Maynard (1995), Arthur (1997) (Burley, Pomphrey 2011, s. 36-41). Od té doby bylo na mentoring nahlíženo jako na klíčový proces při praxích budoucích učitelů. Postupem času tak začaly vznikat mnohé projekty, kurzy a semináře jak pro školy přijímající studenty učitelství, tak pro samotné mentory. V roce 2000 ministerstvo vzdělávání zavedlo oficiálně „tranining schools“, které pomáhaly podporovat partnerství modelu dobré praxe. Podmínkou oficiálního jmenování training school byla tří roční období, v nichž škola hostila budoucí absolventy učitelství. V roce 2008 čítal počet training schools 214 (dle závěrečné zprávy z Houses of Commons 2010). TDA (Training and Development Agency) již od roku 2000 začala poskytovat velkou finanční podporu školám připravujícím studenty i absolventy učitelství, v letech 2002-2006 v rámci Národního Projektu Partnerství zajistila financování pro zaškolení mentorů a podpořila jejich sdílení praktických zkušeností po celé zemi. V letech 2006-2009TDA financovala projektem „Partnerství vývoje škol“ 600 škol, aby zkvalitnila jejich mentoring v praxi. Od roku 2009 TDA společně s vysokými školami připravujícími budoucí učitele prozkoumává další možnosti zlepšení pozic pro budoucí učitele (Houses of Commons 2010). Všechny tyto výše uvedené projekty měly a mají za úkol jediné: zlepšit situaci

4 Má pozornost se zde soustřediuje primárně na Anglii. 
mentoringu na školách a zkvalitnit spolupráci mentorů a vysokých škol (Burley, Pomphrey 2011 s. 37-39). V zárí letošního roku (2015) byl vydán ministerstvem vzdělávání (Department for Education) nově zrevidovaný ${ }^{5}$ dokument Induction for newly qualified teachers (England), který popisuje zavádění nově kvalifikovaných učitelů v Anglii a jenž je volně dostupný na internetu a je určen jako doporučení pro ředitele škol, školní sbor, začínající učitele a příslušné řídící orgány. Zároveň tento dokument definuje povinnosti a práva všech aktérů, kteří jsou zapojeni do prvního roku praxe, jimiž jsou:

1. začínající učitel (newly qualified teacher)

2. vzdělávací instituce, na jejíž půdě probíhá první rok praxe

3. ředitel školy

4. uvádějící tutor - mentor

5. odpovědné orgány

6. rídicí orgány

7. National College for Teaching and Leadership.

V následujícím textu bych ráda vybrala pasáže právě z tohoto dokumentu, který je závazný pro všechny zainterestované strany. Tyto vybrané pasáže se prímo váží k mentoringu a roli mentora, přičemž - jak se domnívám - mohou být významnou inspirací pro formování mentoringu v českém prostředí. Pro lepší pochopení problematiky mentoringu a práce mentora ve Velké Británii se nejprve lehce odchýlím od tématu a vymezím pojem Induction period (tj. první rok praxe) tak, jak jej definuje již zmíněný dokument Induction for newly qualified teachers (England) (2015).

\subsection{Induction period}

Všichni kvalifikování učitelé, kteři jsou zaměstnáni na anglické státní škole, musejí mít dle zákona úspěšně splněný uvádějící rok, tj. první rok praxe (induction period). Na toto období je nazíráno jako na pomysIný most, spojující teoretickou přípravu učitelů (initial teacher training) s jejich profesní praxí. Induction period navíc kombinuje osobním potřebám přizpůsobený program rozvoje, podpory a profesního dialogu s monitorováním a hodnocením výstupů dle odpovídajících standardů učitele (QTS). Tento program by měl podporovat nově kvalifikované učitele v názorném demonstrování svých kompetencí na konci uvádějícího období a vybavit je takovými prostředky, jež jim umožní stát se efektivními a úspěšnými učiteli.

Pro britský model mentoringu je stěžejní, že žádný kvalifikovaný učitel nesmí být zaměstnán jako učitel na státní škole, aniž by úspěšně splnil první rok praxe. V̌̌ichni učitelé, nastupující na první rok praxe, musejí být držiteli QTS. Učitelé, kteří působí

5 Jedná se o aktualizovanou verzi z roku 2013. 
v soukromém sektoru a dalších nevládních a nestátních organizacích, nejsou povinni toto uvádějící období plnit.

Nejdůležitějšími aktéry Induction Period jsou: začínající učitel, uvádějící tutor a ředitel školy.

\subsubsection{Začínající učitel - newly qualified teacher (NQT)}

Pojmem newly qualified teacher se označuje začínající učitel, který úspěšně splnil teoretickou př́pravu na profesi učitele, získal qualified teacher status (QTS), ale ještě nesplnil svůj první rok praxe (induction period). Je zvykem, že NQT nemívají plný úvazek - ten je obvykle naplněn jen z $90 \%$, aby zbýval čas pro konzultace a porady s mentorem, tutorem i ředitelem školy a v neposlední řadě na jejich další profesní rozvoj (Department for Education 2015, s. 29-31).

\subsubsection{Uvádějící tutor - mentor}

Uvádějící tutor neboli mentor je nejbližším spolupracovníkem začínajícího učitele. Dokument definuje uvádějícímu tutorovi tyto povinnosti:

- Poskytovat, koordinovat a vést efektivní podporu včetně coachingu a mentoringu začínajících učitelů a podporovat jejich profesní rozvoj.

- Provádět a zaznamenávat pravidelné hodnocení pokroku začínajícího učitele během prvního roku praxe.

- Vykonat tři velké formální hodnotící setkání během celého roku praxe.

- Zajistit pravidelnou hospitaci začínajícího učitele a poskytnout okamžitou a konstruktivní zpětnou vazbu k hospitované hodině.

- Poradit a podpořit začínajícího učitele při řešení problémů.

- Poskytnout pomoc navíc začínajícímu učiteli, jehož profesní výsledky neodpovídají standardu učitele (Department for Education 2015, s. 31).

\subsection{3 Ředitel školy}

Ředitelé škol jsou společně s příslušným orgánem zodpovědní za monitoring, podporu a hodnocení začínajícího učitele během prvního roku praxe.

Ředitelé by měli:

- Kontrolovat správnost veškeré administrace týkající se správného plnění prvního roku praxe.

- Zajistit zkušeného uvádějícího tutora /mentora a zvážit, zdali tento vyučující má dostatek času pro vykonávání této funkce.

- Zajistit pravidelné hodnocení pokroku začínajícího učitele.

- Zajistit individuální program prvního roku praxe „ušitý začínajícímu učiteli na míru.” 
- Zajistit, aby pokrok začínajícího učitele byl pravidelně monitorován, hodnocen včetně hospitací a následné zpětné vazby.

- Zajistit, že jsou prováděny semestrální hodnocení, sepsány zprávy a ty jsou odeslány př́slušným orgánům.

- Účastnit se řízení kvality pořádané příslušnými orgány.

- Kontaktovat včas př́ślušné orgány, kde hrozí riziko, že by začínající učitel nemusel úspěšně splnit první rok praxe (Department for Education 2015, s. 29-31).

\subsection{Mentor, tutor a mentee}

Kromě výše uvedených pravidel existuje ještě mnoho dalších odborných i populárně naučných návodů, které sice znovu a znovu charakterizují role uvádějícího tutora, ale ve svém jádru vycházejí všechny právě z výše citovaného dokumentu Induction for newly qualified teachers (England).

Jelikož konečným cílem mé připravované disertační práce je přinést do českého prostředí aplikovatelné inspirace ze zahraničí a poskytnout tak našim domácím mentorům jakýsi praktický návod, velmi si cením právě těch publikací a dokumentů, které jsou primárně určeny pro mentory působící ve vzdělávacích institucích. Za velmi názorný a prínosný považuji z tohoto pohledu také dokument A guide for induction tutors (2014)6, jenž velmi podrobně informuje uvádějící tutory o správném postupu při prvním roku praxe a uvádí velmi kvalitní charakteristiku efektivního uvádějícího tutora na straně jedné a zároveň úspěšného absolventa prvního roku praxe (successful NQT) na straně druhé. Všechny tyto charakteristiky vycházejí z mnoha zpětných vazeb uvádějících tutorů, které byly analyzovány ve dvouleté studii tvưrci výše zmíněného dokumentu. Provedený výzkum ukázal, že profesní rozvoj nově kvalifikovaného učitele je výrazně vyšší, když uvádějící tutor plní níže uvedené atributy, podle nichž by měl:

- Poskytnout nově kvalifikovanému učiteli dostatečnou šíri zkušeností a tím mu umožnit úspěšné splnění kladených požadavků.

- Vytvořit otevřené a přátelské klima plné upř́mnosti a důvěry.

- Být plně seznámen se zákonem danými požadavky, které musejí začínající učitelé splnit na konci prvního roku praxe.

- Být tolerantní (open-minded) a být schopen vlastní sebereflexe.

- Seznámit začínajícího učitele s politikou školy.

- Postupovat flexibilně v plánu.

- Disponovat následujícími dovednosti a kvalitami: vnímavost, pochopení, empatie, efektivní naslouchání, dostupnost, podpora, otevřenost, vstřícnost a dobré komunikační schopnosti.

6 Dostupný z: https://www.rbkc.gov.uk/PDF/A \%20guide \%20for \%20induction \%20tutors2013-14_100913.pdf 
- Zajistit uchování veškeré záznamy z monitorování, podpory a formálního hodnocení.

- Využívat a účastnit se setkání s dalšími tutory, kde se společně sdílí nabité zkušenosti a př́klady z dobré praxe.

Úspěšný začínající učitel by naopak měl být otevřený a upřímný, užívat si výuku, mít smysl pro humor, být proaktivním a reflektivním praktikem, přinášet a zkoušet stále nové nápady spojené s neotřelým přístupem. Dále by měl vyhledávat, přijímat a následovat rady zkušeného uvádějicího tutora, měl by být konzistentní v prístupu k výuce a ve vztahu ke svým kolegům. V obecné rovině by měl začínající učitel mít rozumné názory a být po psychické stránce zralý a vyrovnaný, mít rozumné ambice a představy o sobě jako o kvalitním učiteli (tj. mít jasnou představu čeho chce $v$ budoucnosti dosáhnout, kam směřuje a co je jeho profesním cílem). Pochopitelně, že v neposlední řadě by začínající učitel měl mít také odpovídající odborné znalosti.

Na závěr tohoto pojednání tedy nutno podotknout, že ve Velké Británii se o praxi studentů starají nejen univerzity a školy jako zprostředkovatelé, ale i další aktéři, kteří provádějí studenta celou jeho prvotní školní zkušeností. Podle Dixie a Bella (Dixie, Bell 2012, s. 153-156) jimi jsou: externí tutor, který provádí hodnocení studenta s ohledem na standardy učitele, není součástí školy ani univerzity a kontroluje průběh a dokumentaci praxe); profesní tutor, jehož úkolem je dohlížet na průběh praxe studentů, sledovat studentův pokrok a vývoj a rovněž dohližet na spolupráci studenta a mentora (zaměřuje se především na to, zdali se konají pravidelná týdenní setkání, zdali je studentovi poskytován feedback atd.); a konečně mentor. Mentor přidělený NQT, který je vzhledem k tématu mé studie klíčovou postavou celého procesu, má za povinnost informovat začínajícího učitele o škole, interních pravidlech a směrnicích, chodit na hospitace, vést mentorské rozhovory, pomáhat začínajícímu učiteli didakticky i pedagogicky, spolupracovat též s vedením školy a hodnotit učitele z pohledů standardů kvalifikovaného učitele. Třeba ještě zdůraznit, že role mentora je funkcí velmi zodpovědnou, nebot' mentor má pochopitelně velký vliv i na konečné hodnocení učitele a nakonec i finální rozhodnutí, zdali se nově aprobovaný učitel stane učitelem plně kvalifikovaným „s licencí učit."

\section{Závěr}

Z výše uvedených poznatků vyplynulo několik skutečností, jež se mohou stát východiskem pro další bádání v rámci daného tématu. Předně je třeba mít na zřeteli, že fenomén mentoringu je prozatím ještě neuzavřeným a z hlediska svého formování stále "otevřeným" a rozpracovaným instrumentem, jakým Ize zkvalitňovat nejen úroveň pedagogické práce, ale podle naší vstupní devízy i kvalitu školního vzdělávání obecně. $Z$ tohoto důvodu není príliš překvapivé, shledáváme-li co do propracovanosti forem 
mentoringu mezi jednotlivými evropskými zeměmi značné asymetrie, které však samy o sobě - právě proto, že mentoring je stále ještě teprve formujícím se procesem - nemohou být měřítkem celkové kvality vzdělávání v tom kterém státě. Zjevný náskok, který má v oblasti fungování a podpory mentoringu Velká Británie před Českou republikou, je tudíž podle mého soudu především důsledkem pružnějších legislativních podmínek, nežli vyšší úrovně školství jako celku. Aniž bychom tedy sklouzli k lacinému volání po mechanické recepci všeho „západního“, můžeme pohlížet na anglický model jako na cennou inspiraci, jež nám může být významnou nápovědou při hledání vhodných cest k podpoře mentoringu i v českém prostředí. A jelikož je školství nedílnou součástí kultury dané země, je jasné, že ani aplikace mentoringu v České republice nemůže probíhat cestou prostého převzetí britského modelu, nýbrž s ohledem na specifikum našich vlastních kulturních, edukačních i legislativních podmínek. Proto se domnívám, že je třeba inspiraci britským modelem nadále doplňovat a rozšiřovat i o jiné zahraniční reflexe mentoringu, vzhledem k české regionálně-kulturní zakotvenosti především modelu německého. Takový pohled však již přesahuje tematický rámec této studie.

\section{Literatura}

A guide for induction tutors. (2014). [online]. Dostupné z: https://www.rbkc.gov.uk/PDF/A \%20guide \%20for \%20induction \%20tutors2013-14_100913.pdf.

Burley, S., \& Pomphrey, C. (2011). Mentoring and coaching in schools: Collaborative professional learning inquiry for teachers. London: Routledge.

Česká asociace mentoringu ve vzdělávání. (2015). [online]. Dostupné z: http://www.camv.cz/

Dixie, G., \& Bell, J. (2009). Trainee Primary teacher's handbook. London: Continuum

Duschinská, K. (2010). Mentoring v procesu stávání se učitelem (Disertační práce). Praha: Pedf UK.

Frieß, A. (2010). Mentorenarbeit: Betreuung, Beratung und Beurteilung von Referendaren. Buxtehude: Persen.

Induction for newly qualified teachers (England) (2015). [online]. Dostupné z: https://www.gov.uk/ government/uploads/system/uploads/attachment_data/file/458233/Statutory_induction_ guidance_for_newly_qualified_teachers.pdf

Kargerová, J. (2008). Nabídka školení Neslyší potřeby učitelů. Rodina a škola. Časopis pro všechny rodiče a učitele, 55(8), 7-9.

Nešpor, M. (2005). Fakultní učitel - mentor. Moderní vyučování. Časopis pro nové programy v českém základním školství, 11(2), 6-7.

Píšová, M., \& Duschinská, K. (2011). Mentoring v učitelství. Praha: Univerzita Karlova.

Spilková, V., \& Tomková, A. a kol. (2015). Klinická škola: a její role ve vzdělávání učitelü. Praha: Retida spol. s.r.o.

Šneberger, V. (2014). Metodika práce s kompetenčním modelem. Kompetenční model [online]. Dostupné z: http://www.kvalitaskoly.cz/sites/default/files/METODIKA_KOMPETENCNI_MODEL. pdf

TDA teacher: Teacher training. (2014). [online]. Dostupné z: http://www.tda.co.uk/

Training of Teachers: Fourth Report of Session 2009-10. (2010). [online]. Dostupné z: http://www. publications.parliament.uk/pa/cm200910/cmselect/cmchilsch/275/275i.pdf 
Tomková, A., \& Spilková,V. (2012). Rámec profesních kvalit učitele: Hodnotící a sebehodnotící arch. (2015). [online]. Dostupné z: http://www.nuov.cz/uploads/AE/evaluacni_nastroje/08_Ramec_ profesnich_kvalit_ucitele.pdf

Vychodil, D. (2011). Zvnějšku, či zevnitř? / mentoring ve školní praxi. Rodina a škola. Časopis pro všechny rodiče a učitele, 58 (7), s. 26-27.

\section{Kontakt}

Mgr. Andrea Pazderská

Katedra primární pedagogiky, Pedagogická fakulta Univerzity Karlovy

M. D. Rettigové 4, 11639 Praha 1, Česká republika

E-mail: andy.novotna@gmail.com 